\title{
関節リウマチ治療中に経験せるリウマチ性肺臓炎
}

熊本大学整形外科

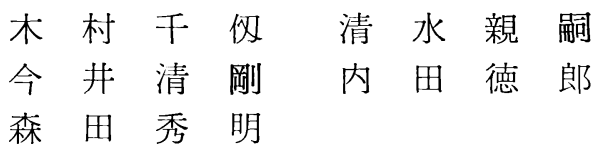

熊本大学第一内科

野津手 晴 男

\section{Rheumatoid Pneumonitis in Patients with Rheumatoid Arthritis}

By

\author{
C. Kimura, K. Imai, T. Uchida, \\ C. Shimizu \& H. Morita
}

Dept. of Orthop. Surg. Kumamoto Univ. Med. Sch.

\section{H. Nozute}

Dept. of 1st Int. Med. Kumamoto Univ. Med. Sch.

\begin{abstract}
Pulmonary disease associated with rheumatoid arthritis or collagen diseases were noted recently in Japan.

Three cases with rheumatoid pneumonitis were reported while the patients with rheumatoid arthritis was treated in our clinic. They were patients with definite or classical rheumatoid arthritis, and had a cough, dyspnea, shortness of breath and sense of a vise. The Co-relation between the stage and the appearance of rheumatoid pneumonitis was not clear. The chest film revealed the fibrosing pneumonitis or diffuse interstitial fibrosis with a strand or nodular shadow. Respiratory examination revealed low function. The treatment using corticosteroid was successful for the rheumatoid pneumonitis.
\end{abstract}

慢性関節リウマチ（以下RAと略す）は，結合織の 炎症性変化を特徵とする全身性疾患であるが, その主 病変は関節である. 一方 1845 年 Latham がリウマチ に合併せる肺炎の症例を報告して以来，時折報告を みるが, 近時 Brannan (1964), Talbott (1964), Patterson (1965), Rubin (1967) や,また吾国では 大里 (1957), 本間 (1963), 大島 (1963), 荻間 (1969) らにより種々検討され, 注目されるようになった.

今回吾々は, とかく関節症状を中心として整形外科 的に観察治療をすすめている R A 患者から, 最近 3 例 のリウマチ性肺臓炎と思われる症例を経験したので報 告する.

[症例 1 C.K. 女 30 才

Definite RA Class 1 . Stage 1.
既往歷： 21 才で虫垂切除術. 28 才時, 卵巣出血で 出術.

現病歴：S. 41 年春頃より手指関節の腫脹と朝のと わばりがあり, 某医で Corticosteroid 症法をうけて いた. その後, 全身の関節痛と $37^{\circ} \mathrm{C}$ 代の発熱が続い ていた. S. 42.7 当科を訪れ Aspirin. Tanderil 投与 や金療法をうけ，症状は軽くなっていた． S. 43.11 感 冒に罹り咳嗽ひどく声も出難くかったが，2週間で治 ゆした. S. 44.1 再び感冒に罹り, $37^{\circ} \mathrm{C}$ 代の発熱あ り, Rinorrhoe ああった. S. 44.2 息切れを自覚する ようになり，内科受診をすすめた．当時，心・肺・ 腹部に打・聴・触診上著変なかったが, 胸部レ線上 rheumatoid pneumonitis の疑があり, S. 44.5.6 内 科入院.

理学的検査: 体温 $36^{\circ} \mathrm{C}$ 代, 肝機能正常喀痰(一), 
表 1 臨床検査所見

\begin{tabular}{|r|r|r|c|c|c|c|r|}
\hline $\begin{array}{c}\text { 症 } \\
\text { 例 }\end{array}$ & $\begin{array}{c}\mathrm{R} \\
(\text { 万 })\end{array}$ & $\mathrm{W}$ & $\begin{array}{c}\mathrm{Hb} \\
(\mathrm{g} / \mathrm{dl})\end{array}$ & $\mathrm{CRP}$ & $\mathrm{RA}$ & $\begin{array}{r}\mathrm{r}-\mathrm{G} \\
(\%)\end{array}$ & $\begin{array}{c}\text { 赤沈 } \\
\left(\begin{array}{l}\mathrm{mm} / \\
\text { 1時間 }\end{array}\right.\end{array}$ \\
\hline 1 & 487 & 11200 & 13.6 & $2+$ & + & 17.9 & 31 \\
2 & 380 & 8600 & 13.9 & - & H & 17.9 & 34 \\
3 & 444 & 16400 & 13.6 & $6+$ & 以上 & 21.9 & 116 \\
\hline
\end{tabular}

Sediment (一), 屎の潜血反応 (一). 血清蛋白分画, 電解質など正常. 17-OHCS は $0 \mathrm{mg} / \mathrm{day}$. 肺は呼吸 音弱いガラ音 (一). 他の 検査成績は表 1 のとおりで ある。

胸部レ線像第 1 肋間以下両側肺野全般に索状結節状 陰影を示し，右横隔膜縁がやや不整である.（写真1)

肺機能検查では, 肺機能検查では, 肺内因子・呼吸

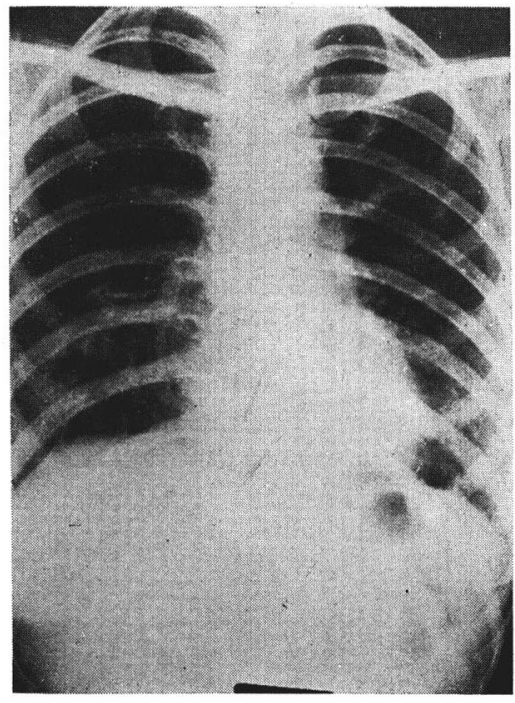

写真 1 症例 1 胸部レ 線像
筋・胸廓の何れかによる拘束性障害が認められる．治 療として Indomethacine $75 \mathrm{mg}$, Irotycin $600 \mathrm{mg}$, Aspirin $1.5 \mathrm{gr}$ を 1 日量とし, methylprednison 12 $\mathrm{mg} / 1$ 週 筇注を施行中であるが, 自覚症は消失せる あ肺所見は不変である.

[症例 2〕 Y.N. 女 38 才.

Definite RA Class 1. Stage 2.

既往歴：特記すべきものなし.

現病歴: S. 40.8 多関節痛をむって発病. 某医にて 治療をうけていた. S. 43.9 当科外来にて 金療法 と Ibufenac の併用療法を施行. S. 43.11 胸がつまった 感じがあり，内服投与を中止して消失した． S. 43.1 Morning Stiffness (一). 自覚的にも症状ほとんど消

表 2 呼吸機能検査報告書（一般検查）

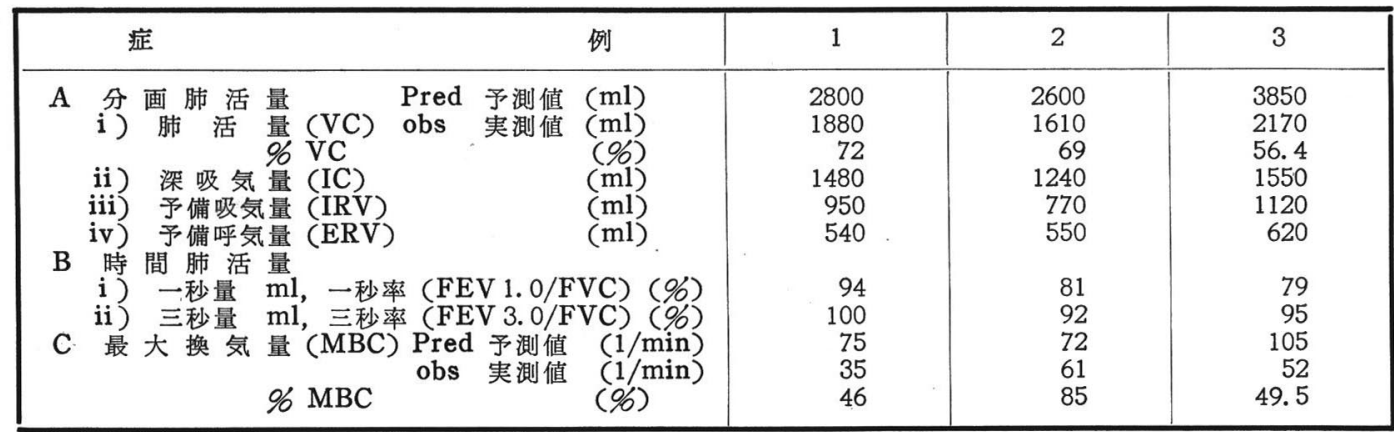


失. 赤沈 1 時間值 $14 \mathrm{~mm}$. $17 \mathrm{KS} 9.83 \mathrm{mg} / \mathrm{day}, 17-$ OHCS $1.43 \mathrm{mg} /$ day. S. 44.3 軽い咳嗽と胸部の圧迫 感あり. 呼吸困難 (一). 動悸 (一). 内科受診させ Rheumatoid fibrosis と診断. S. 44.5 第療法中止.

理学的所見: 体温 $36^{\circ} \mathrm{C}$ 代. ECG 正常, 血清蛋白 分画正常. おの他は表 2 のとおり. 心・腹部には全く 所見なし. 肺は右下肺野に湿性ラ音 $(+)$. 胸部レ線 像で, 両側第 1 肋間以下に両側肺門部上り放射状に拡 がる結節性, 索状陰影あり. 心陰影の肥大 (十). 肺 機能検査で換気機能はおおむね正常なるも拡散能力が 軽度低下.

治療: Indomethacine, Alotec など投与中なるも, 現在まで所見変らず.

[症例 3] S. T. 男 43 才.

Classical RA Class 4. Stage 3.

既往歴：20 年前に Myositis.

現病歴: S. 41.12 頃より両膝関節痛のため某医で Corticosteroid 投与をうけていた. S. 42.10 仕事の あと Polyarthralgie が起り, 以後病院を転々として Corticostereid 療法を続けた. S. 43.4 動けなくな り症状も動けなり症状も悪化したため某院に入院.

S. 43.10 Stereid 離脱の目的で当科入院. Aspirin, Phenylbutazone, Gold などによる Steroid の漸減 を計った. S. 44.4 呼吸困難を訴えるようになり, 内 科受診.

理学的所見：体温 $37^{\circ} \mathrm{C} \sim 38^{\circ} \mathrm{C}$ 代，血清蛋分画で Albumin 38.8\%，r-G 21.9\%. 電解質正常. 17OHCS $0.56 \mathrm{mg} / \mathrm{day}$. その他は表 2 のとおり. 肺は 両側下肺野に著明な湿性亏音 (十), 呼吸音の減弱, 呼気の延長あり. 胸部レ線像で, 左第 $1 \cdot 2$ 肋間に索 状陰影, 第 2 肋間内側に円形・びまん性陰影があり, 右第 2 肋間に索状・結節状陰影ありて Lungen fibrose を思わせる. さらに Stauungs pneumonie を 起していると思われる. 肺機能検査で拘束性障害が認
められる.

治療: Corticosteroid 剂, 抗生物質, 消炎酵素剂 などの投与により, 症状は軽快.

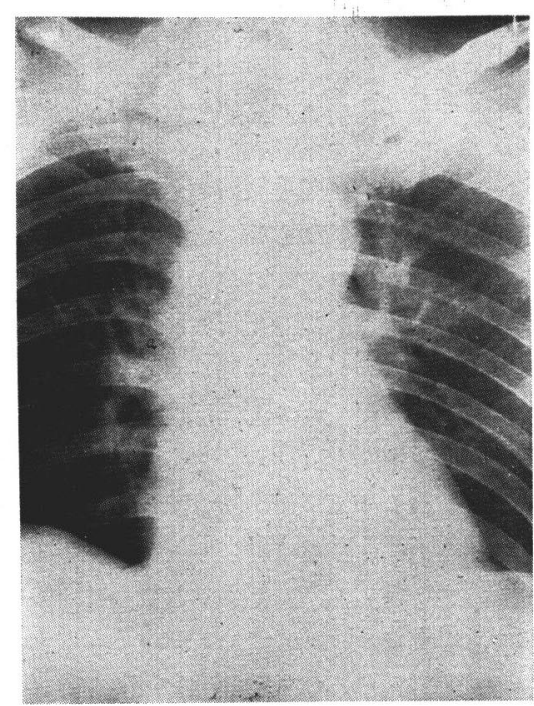

写真 3 症例 3 胸部レ線像

$$
\text { 考按 }
$$

従来, R A 関して, 肺病変が高度で呼吸器症状を 訴える症例は, 特器な例として報告されており, この ような患者の比率は決して高いものではない. 1965年 Patterson は各国の文献上, 32例の判然とした rhuematoid lung disease) に自験例 9 例を加えて報告 し, その後む Rubin, Petty その他の研究者により追 加検討がなされつつある.

最近吾国でも大島 (1963), 萩間 (1969) らをはじ め, 幾人かの研究者の報告があり注目されてきたとと は, 本年の日本リウマチ学会でシンポジウムとして取 上げられた事からあわかる。

病理形態学的には，肺胞内滲出を主体とする肺炎 と, 肺胞壁・間質の支持組織における炎症を主体とし

表 3 呼吸機能検査報告書（機能的残気量及び残気量）

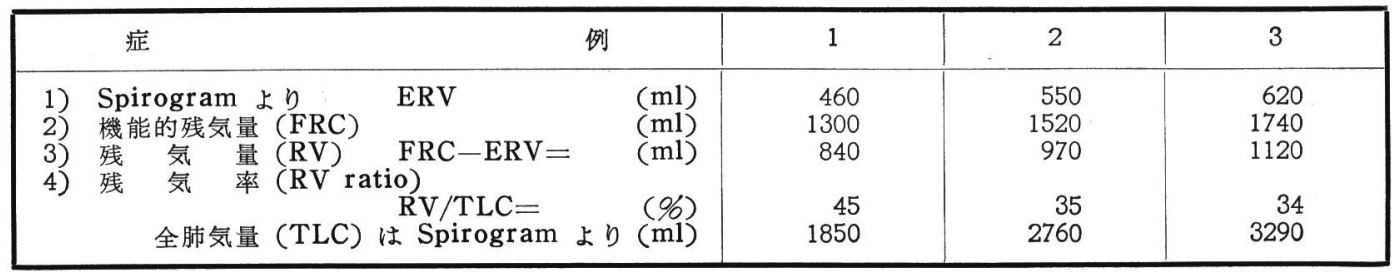


慢性のものでは肺線維症となる肺臟炎に 分けられて いる.

頻度の多少は, 報告者によりまちまちであるが, 大 島らは, P A 184 例中肺線維症に似たレ線像を示した あのが 59 例 (32.1\%) あり, 特にその大半が 40 才 以上である事を示した．吾々は，今年 1 月以降当科外 来を訪れた P A 171 例中 3 例 $(1.75 \%$ ）であった.

Stage 之肺変化之の間には何等の関係を見出し得な いが, 斉藤は䍜患年数の長いものに本症の出現が高率 にみられる傾向があるという．また吾々の 3 症例とも 関節症状が先行し, 呼吸器症状は, 前者の治療中に見 られたあので，一般の報告と同じである.

発症は, 急性に起るむの之潜行性または慢性に起る あのとがあり, 第 3 例は前者, 第 $1 \cdot 2$ 例は後者に属 する. 前者ではP A の経過中に急激な発熱, 咳濑, 呼 吸困難などを示し, 後者では, 感冒様の症状で軽い咳 濑・息苦しさを訴える．胸部所見む少なく，時にラ音 を聴取する程度で, 吾々の例であ同様であった. 関節 症状と肺病変の起る時期的関係について, Ellman （1948）らは関節に早期活動期病変あるものを報告し， Hart (1955) その他は関節症状之同時または再燃時の 発病例を報告しているが，大島らは，てれらの相関を 否定しており, 吾々の例でも関節症状と肺病変の発症 時期について相関は得られなかった. 肺レ線所見は， び慢性間質病変を推測させる線状・網状・点状または 斑状の多彩な像を示し, Petty らは（表4）のごとく 5 つに分類している.

\section{表 4}

\begin{tabular}{|l|}
\hline $\begin{array}{c}\text { Five Roentgenographic Manifestations } \\
\text { of Rheumatoid Lung }\end{array}$ \\
\hline 1. Chronic Fibrosing Pneumonitis \\
2. Diffuse Interstitial Fibrosis \\
3. Discrete Nodules with or without cavita- \\
tion \\
4. Rheumatoid Pneumoconiosis (Caplan's \\
5. Pyndrome) Pleurisy with Effusion \\
\hline
\end{tabular}

臨床検查所見では, 慢性に発症した第 $1 \cdot 2$ 例で は, P A テスト陽性, 赤沈中等度䒕進を示し, 第 1 例 に Leucocytose, CRP $(+)$ を認めたが, 第 3 例では Leucocytose, CRP $(6+7) \mathrm{RA}(+), \mathrm{r}-\mathrm{G}$ 上昇, 赤 沈高度え進を示した。一般には, 上記変化の他に慢性 貧血をみるという(萩間).

肺の理学的所見が軽いのに比し，著明な肺機能の低
下がみられることがあるというが，第 1 ・3 例はとも に拘束性障害之時間肺活量は減少せずに肺活量のみ減 少し, 第 2 例では, 軽度の拡散能力低下をみた。（笹 本)

治療としては副腎皮質ステロイドが著効を示し，そ の他抗リウマチ剂の投与などで経過をみることがよい とされている．吾々の第 $1 \cdot 3$ 例は C S 投与と antibiotica その他抗リウマチ剂投与で自・他覚的にかな りの改善が得られたが，第 2 例は，自覚症の改善はみ たものの，他覚的所見はなお不変である.

$$
\text { むす び }
$$

以上我々は臨床所見よりリウマチ性肺臟炎と思われ る 3 例を検討したが, Biopsy による組織検査を行っ ていないので，更に確実なととは言えないが，PA治 療中に，もし軽い咳嗽・呼吸困難，胸部圧迫感などを 訴える患者があった場合，一応本症を疑い，内科にて 胸部精査の上, 治療観察を行なう必要がある事を強調 するむのである.

\section{参 考 文 献}

1) Brannan, H. M. et al. : J. A. M. A. Vol. 189: 914, 1964.

2) Talbott, J. A. et al. : J. A. M. A. Vol. 189: 911, 1964.

3) Patterson, C. D. et al.: Ann. Int. Med. Vol. $62: 685,1965$

4) Rubin, E. H. et al.: Am. J. Med. Vol. 42 : $567,1967$.

5）大里俊吾：日本臨床. Vol. 15：1432，1957.

6）本間光夫 - 他：治療. Vol. 45, No. 6: 1169, 1963.

7）大島良雄・他：日本臨床. Vol. 21：881, 1963.

8）荻間 勇：日医新報. No. 2239 : 87, 1967.

9) Petty, J. L. et al. : Dis. Chest. Vol. 49: 75, 1966.

10）原沢道美 - 他：治療。Vol. $51 ： 119,1969$.

11）荻間 勇：日本臨床. Vol. 27：44, 1969.

12) Rubir, E. H.: Am. J. Med. Vol. 19: 569, 1955.

13）斎藤泰弘：第 13 回日本リウマチ学会. 東京, 1969. 5, 口演.

14）笹本浩・他:「スパイログラムの臨床」医学書 院, 東京, 1959.

\section{質問 九大温研 定村 章二} 結節性陰影の場合気管支肺炎との鑑別はどのように 
したか. Fibrosis はレ線上肺周囲辺部に比較的著明 といわれているがその点は，治療経過は

回答熊本大 木村 千伋

内科の協同研究者にきいてみる，自覚症である咳， 呼吸困難は消失または軽減したが, レ線陰影は現在の 所不変である.

質問鳥取大 長谷川 淳

Pneumonie $と$ Pneumonitis の語原的, 病理学的 差異について

回答

熊本大 木村 千仅

肺胞内渗出が溜っている場合を Pneumonie, 肺胞 壁, 間質組織の炎症増殖性変化が強い場合を Pneu- monitis としてわけられている

質問長崎大 田口厚

$\mathrm{RA}$ 患者治療中特に CS 投与中に抢いても肺線維症 様症状を呈する例があるが，乙れがリウマチ性の病変 か, CS 投与による感染 (慢性気管支炎) 加判断に迷 うことがある. この際の抗生物質の投与に意義がある か. 肺病変と CRP の相関関係があるか否か.

回答熊本大 木村千仅

第 1 例および第 3 例では CS 上抗生物質の併用を行 なっているためいずれが奏効しているか明確にはわか らないが，文献的には CS の効果が強調されている. $\mathrm{CRP}$ と肺病変との相関は現在内科と調査中で結果が 出ておらずお答えできない。

\title{
慢性関節リウマチ患者にみられる股関節の変化
}

鳥取大学整形外科

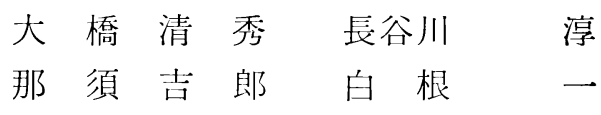

\section{Pathological Changes in the Hip Joint of Chronic Rheumatoid Arthritis}

By

\author{
K. Ohashi, K. Hasegawa, Y. Nasu \& Shirane \\ Department of Orthopedic Surgery, Tottori University, \\ School of Medicine
}

\begin{abstract}
In early rheumatoid arthritis, the hip joint is rarely affected. The hip joint is involved in severe classical rheumatoid arthritis and is similar to osteoarthritis roentgenographically in those cases.

On the hip joint, in the early stage of classical rheumatoid arthritis roentogenographically general narrowing of the joint space and bone atrophy are characteristic. On the other hand, irregular narrowing of the joint space, new formation of bone cystes and spicular formation are beginning in the early stage at the weight bearing part.

It is worthwhile to be followed up that oteoarthritic changes were noticed at the early stage of rheumatoid arthrits in a few cases treated with intra-articular injection of steroids into the hip joints.
\end{abstract}

慢性関節りウマチ患者のうち，股関節に病変がある あのは比較的まれである. しかし Stagt が進行した
あのには, 股関節の変化をしばしば認める. そのX線 像は変形性股関節症に類似している. 初期の股関節像 